\section{Journal of Sciences and \\ Engineering}

Vol. 5, $\mathrm{N}^{\circ}$ 2, 2021

\title{
Alkaline activation of mortars made from solid construction waste [Activación alcalina de morteros fabricados a partir de residuos sólidos de construcción] \\ Cesar Arevalo Aranda ${ }^{a}$, Segundo Acevedo Zavaleta ${ }^{b}$, Alexander Vega Anticona ${ }^{b}$ \\ aEscuela de Ingenieria de Metalurgica, Universidad Nacional de Trujillo - Av Juan Pablo s/n, Trujillo, Peru \\ ${ }^{\mathrm{b}}$ Escuela de Ingenieria de Materiales, Universidad Nacional de Trujillo - Av Juan Pablo s/n, Trujillo, Peru \\ *carevalo@unitru.edu.pe
}

Received: 20 November 2021; Accepted: 15 December 2021; Published: 18 December 2021

\section{Resumen}

En la presente investigación se evaluó la influencia del porcentaje en peso de reemplazo de cemento portland (CP) por polvo de concreto reciclado (PCR), activado alcalinamente, en porcentajes de $10 \%, 20 \%, 30 \%, 40 \%$ y $50 \%$, los cuales fueron seleccionados de escombros de construcciones dejados en el balneario de Buenos Aires, distrito de Víctor Larco Herrera, provincia de Trujillo. Luego de ser lavados, pasaron al proceso de molienda y tamizado (malla № 400), utilizándose solo el material pasante. Se fabricaron probetas según norma ASTM C-109 para el ensayo de compresión en morteros de cemento, para la solución alcalina se utilizó $\mathrm{NaOH}$ (4M). Los morteros obtenidos se curaron en una estufa a $70{ }^{\circ} \mathrm{C}$ durante 72 horas, y posteriormente terminó el curado a temperatura ambiente, durante un tiempo total de 28 días. Los resultados del ensayo a compresión promedio fueron de $12.15 \mathrm{MPa}$, en el caso del mortero de CP y de 14.25 MPa en el mejor de los casos (mortero de CP y PCR-10\%), siendo el incremento del $17.28 \%$. El diseño de mezcla utilizando arena gruesa y aglomerante se mantuvo constante en (3:1), mientras que la relación agua/cemento (a/c), fue de 0.6 en todos los casos. La razón del incremento de la resistencia a la compresión se debe a la reacción entre las partículas de PCR, solución alcalina y el hidróxido de calcio producido durante la hidratación de las partículas de cemento, los cuales generan geles (CASH), los que ocupan los espacios dejados por el proceso de hidratación de las partículas de cemento mencionado, pues necesitan del hidróxido de calcio. Para todos los casos del ensayo a compresión se realizaron un total de 10 repeticiones.

Palabras clave: Activación alcalina, Concreto reciclado, Resistencia a la compresión.

\begin{abstract}
In the present investigation the influence of the percentage by weight of replacement of portland cement $(P C)$ by recycled concrete powder (RCP), alkaline activated, in percentages of $10 \%, 20 \%$, $30 \%, 40 \%$ and $50 \%$, was evaluated. which were selected from construction rubble left in the Buenos Aires spa, Víctor Larco Herrera district, Trujillo province. After being washed, they went to the grinding and sieving process (400 mesh), using only the through material. Specimens were manufactured according to the ASTM C-109 standard for the compression test in cement mortars, for the alkaline solution $\mathrm{NaOH}(4 \mathrm{M})$ was used. The mortars obtained were cured in an oven at 70 - $\mathrm{C}$ for 72 hours, and subsequently the curing was completed at room temperature, for a total time of 28 days. The results of the average compression test were $12.15 \mathrm{MPa}$, in the case of the PC mortar and 14.25 MPa in the best case (PC mortar and RCP-10\%), the increase being $17.28 \%$. The mix design using coarse sand and binder was kept constant at (3:1), while the water / cement ratio $(\mathrm{w} / \mathrm{c}$ ) was 0.6 in all cases. The reason for the increase in compressive strength is due to the reaction between the RCP particles, alkaline solution and the calcium hydroxide produced during the hydration of the cement particles, which generate gels $(\mathrm{CASH})$, which occupy the
\end{abstract}




\section{SE

Vol. 5, $\mathrm{N}^{\circ}$ 2, 2021

Copyright @ 2021, CINCADER.

ISSN 2523-9503

DOI: https://doi.org/10.32829/sej.v5i2.149

spaces left by the hydration process of the aforementioned cement particles, as they need calcium hydroxide. For all cases of the compression test, a total of 10 repetitions were carried out.

Keywords: Alkaline activation, Recycled concrete, Compressive strength.

\section{Introduction}

One of the most relevant cases associated with the use of concrete waste, perhaps the use of the rubble from the Berlin wall, used in the construction of new homes, in this way in the countries of the European Union and North America, already They have projects that have been progressively developed over the years, developing new products from construction waste, as well as environmental regulations that force raw materials from previous demolitions to be used in construction works, with the aim of make the most of the potential that these residues have (Cabrera et al., 1997). In Peru, the construction sector is one of the economic activities with the greatest impact, its status is considered a unit of measurement of national economic well-being; It is also a sector with high employment generation (Lima Chamber of Commerce, 2019) In the city of Trujillo in recent years, the increase in this sector has been evidenced, thus new projects in the construction of apartment buildings are observed every day, projects in the public sector, self-construction, among others, although this is equivalent to the progress of cities, this increase also implies the generation of greater amounts of construction waste; waste that despite the efforts of the municipalities for its management and disposal, these are not popular among citizens, so these waste often end up in places not suitable for it (riverbanks, places near coastal beaches, roadsides), this situation has captured the attention of citizens, for this reason every day the interest in using construction and demolition waste in applications such as precast concrete is increasing, one of the options being the reuse of these waste alkaline activation This is due to its low cost of reagents and easy adaptation in the traditional processes associated with the area of precast cement (Bravo, 2011).

Mesgari et al. (2020), proposes as an alternative for the management of construction and demolition waste the process called geopolymerization, which could be included in conventional cement mixtures, in this case as partial or total replacement of aggregates and / or binder (depending on the expected strength and the grinding process used); from results obtained by replacement by geopolymerized recycled concrete by coarse aggregate $(20 \% \mathrm{w})$, the very small reduction of the modulus of elasticity in flexion, resistance to compression and porosity and of the mixture obtained is verified; the replacement increases (50\% and $100 \%)$, generated a significant decrease in the mentioned properties, for which it is concluded that it is necessary to study a greater spectrum of replacement percentages, evaluate the original mix design, water / water ratio cement to be used and the economic coherence of possible replacements. Rakhimova \& Rakhimov (2015), evaluated the effect of the concentration of the alkaline activator, type of activator, temperature, curing time, chemical composition of ceramic residues, its mineralogy, particle size of recycled ceramic aggregate and water - binder ratio, on mechanical properties of a so-called geo-cement ", they concluded that the degree of impact of the mentioned variables on the mechanical resistance is: type of activator > percentage of material replacement> grinding method of ceramic waste $>$ curing conditions $>$ composition and origin of the ceramic residues, this is due to the fact that the type of activator used is responsible for dissolving the active components of the ceramic aggregates. Curing at a temperature higher than room temperature will accelerate geopolymerization reactions and promote the formation of a homogeneous structure. The water / binder ratio will influence obtaining a denser structure for a water / binder ratio range of $0.4-0.6$; this depending on the type of binder material (brick dust, fly ash, blast furnace slag, etc.). Shi et al. (2012), evaluated the influence of the limestone production and addition parameters on the microstructure and mechanical properties of geopolymerized mortars and pastes based on fly ash, the results obtained show an increase in resistance to the compression of the geopolymerized mortar based on fly ash and limestone, values that correlate with the increase in the dose of alkaline activator used, until reaching a maximum and then decreasing the mentioned 


\section{SE \\ Journal of Sciences and Engineering}

Vol. 5, No 2, 2021

Copyright @ 2021, CINCADER.

ISSN 2523-9503

DOI: https://doi.org/10.32829/sej.v5i2.149

values; The improvement is due to the fact that the geopolymerization reactions developed, which in turn are strongly dependent on the conditions of the production process (curing temperature at early ages, concentration of alkaline solution, mixing dosage, total curing time, among others). ( $\mathrm{Ng}$ et al., 2018).

The review of articles developed, focuses on the analysis of microstructures of various geopolymerized binders; Analysis reveals that the different molarity of the sodium hydroxide or phosphoric acid solution, the solution/binder ratio, temperature, and cure time produce geopolymers of various properties. Most of the geopolymers obtained show an amorphous structure of aluminosilicates; In addition, aged geopolymers have a denser matrix arrangement and therefore increase the resistance to compression. Geopolymerization avoids the interconnectivity of micropores due to the formation of a denser geopolymer gel matrix. Generally, the use of a sodium hydroxide solution $12 \mathrm{M}$, a low liquid to binder ratio of about 0.4 , and a cure temperature of about $70{ }^{\circ} \mathrm{C}$ for at least 24 hrs produced high strength geopolymers.

\section{Materials and methods}

The study material consisted of $5 \mathrm{~cm} \times 5 \mathrm{~cm} \times 5 \mathrm{~cm}$ cubic mortars, according to the ASTM C109 standard; With replacement percentages by weight of $0 \%, 10 \%, 20 \%, 30 \%, 40 \%$ and $50 \%$ of portland cement by recycled concrete powder, a total of 10 compression tests were carried out at all the mentioned levels; The mix design used for coarse sand and binder remained constant at $(3: 1)$, while the water/cement ratio $(\mathrm{w} / \mathrm{c})$ was 0.6 in all cases.

The Recycled Concrete powder (RCP) was obtained by grinding recycled concrete particles (5 $\mathrm{cm}$ ) in a ball mill, the grinding time was 12 hours, once the recycled concrete powder was obtained this step by sieving (mesh No. 400), using only the through-wire of the aforementioned mesh.

As alkaline activator, sodium hydroxide $(\mathrm{NaOH})$ in pellets at $98 \%$ purity and at a concentration of $4 \mathrm{M}$ was used, for preparation distilled water was used, the water / binder ratio was kept constant at 0.6 , the mentioned alkaline solution was used for the Mixing of the mortars, being added in 3 portions in all cases, the mixing was carried out manually, keeping the mixing time constant at 20 minutes.

To obtain the mortar cubes, wooden agglomerate molds were used, release agent was added to these before filling, the molds were filled in three stages, in each of them the mortar was rammed against the molds. in order to reduce the possibility of void formation. After 24 hours, the mortars obtained were demolished to go to the curing process in an oven at $70^{\circ} \mathrm{C}$ for 72 hours, and then $\mathrm{tl}$ finished curing at room temperature, for a total time of 28 days. Finally, the mortars were tested under compression. The compression test was carried out in a universal testing equipment brand Tectotest with a capacity of 60 Ton.
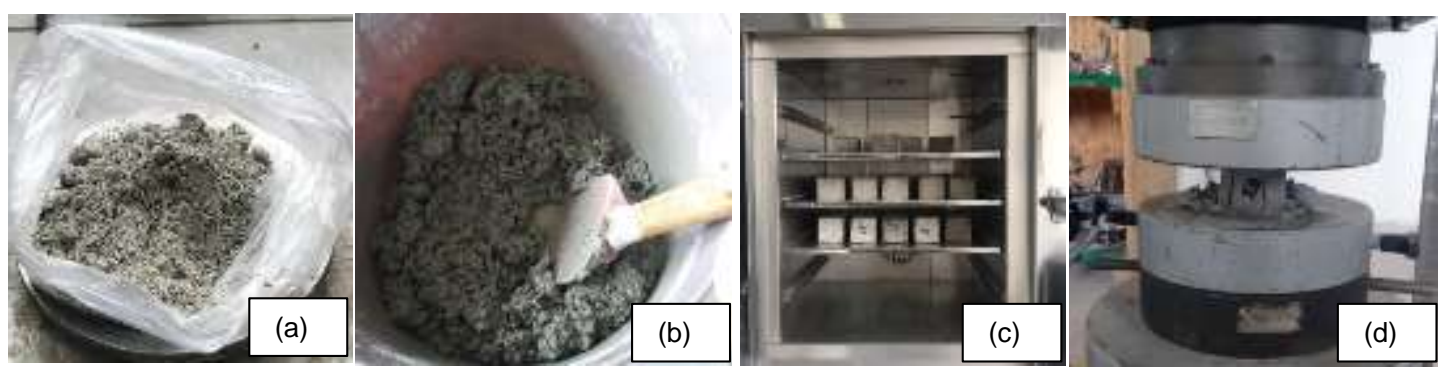

Figure 1. Process of obtaining and compression tests of alkaline activated mortars. (a) Recycled concrete powder; (b) Mortar mixture obtained; (c) curing mortars; (d) compression test of mortars obtained. 


\section{Journal of Sciences and \\ Engineering}

Vol. 5, $\mathrm{N}^{\circ} 2,2021$

Copyright (c) 2021, CINCADER.

ISSN 2523-9503

DOI: https://doi.org/10.32829/sej.v5i2.149

\section{CINCADER}

Centre of Research and Training for

Regional Development Online at www.journals.cincader.org

\section{Results}

Compressive strength:

Table 1 and Figure 2 show the average values of the compressive strength of mortars obtained by the replacement of PC by alkaline activated RCP

Table 1. Average values of compressive strength of mortars (MPa)

\begin{tabular}{cc}
\hline Replacement percentage & Compressive strength (Mpa) \\
\hline 0 & 12,15 \\
10 & 14,25 \\
20 & 13,04 \\
30 & 12,45 \\
40 & 12,36 \\
50 & 11,97 \\
\hline
\end{tabular}

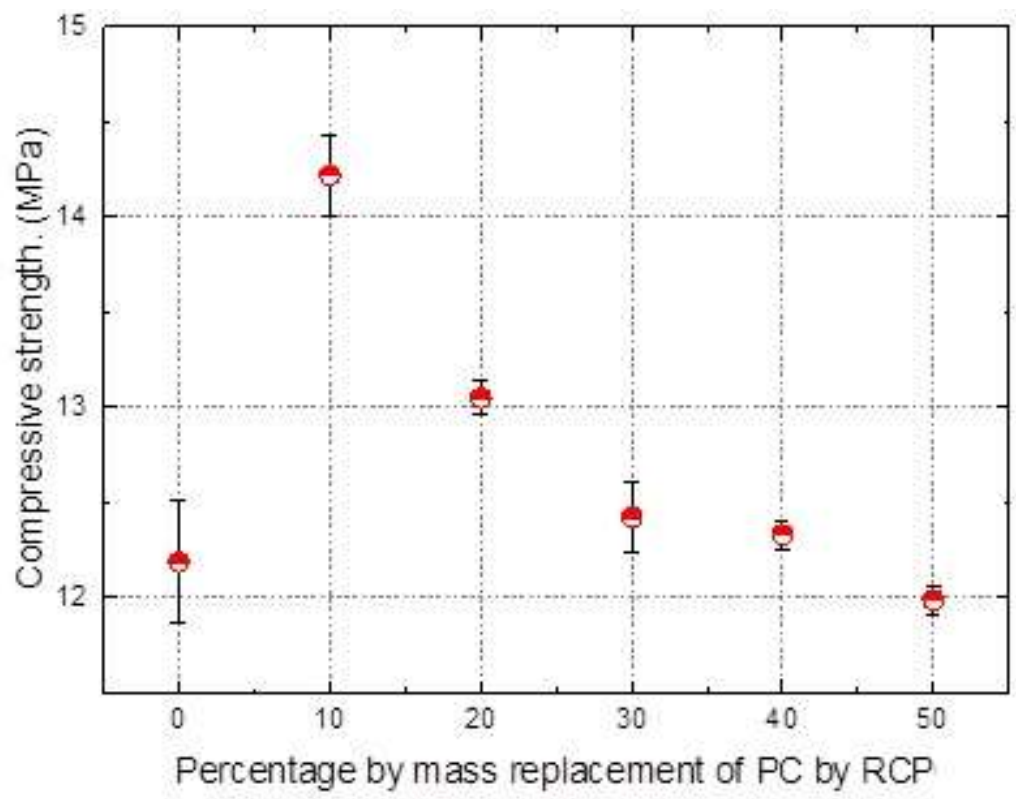

Figure 2. Average values of mortar compression resistance (MPa).

In figure 2, an increase in compressive strength in mortars with replacement of recycled concrete powder (RCP) can be seen from $10 \%$ to $30 \%$, the largest increase being with the replacement of $10 \%$ with values compressive strength of $12.15 \mathrm{MPa}$, in the case of PC mortar and $14.25 \mathrm{MPa}$ in the best case (PC mortar and RCP-10\%), the maximum increase obtained being $17.28 \%$; This increase is due to the alkaline activation process on the RCP which generates soluble silica for the formation of extra hydrated silicate gels $(\mathrm{C}-\mathrm{S}-\mathrm{H})$ and also the formation of hydrated calcium aluminosilicate gels (C-A-S-H); the additional gels are formed in the voids that are generated in 
Vol. 5, $\mathrm{N}^{\circ} 2,2021$

\section{SE \\ Journal of Sciences and Engineering}

Copyright (c) 2021, CINCADER.

ISSN 2523-9503

DOI: https://doi.org/10.32829/sej.v5i2.149

the hydration of the cement, in this way the formation of the extra gels helps in the formation of a higher density structure and therefore greater compaction; This being the cause of the increase in the resistance to compression found; Figure 3. (a) and (b) shows the improvement with respect to the increase in the density of the mortar obtained. In the same figure 2, the decrease in the improvement of the compressive strength from the replacement percentage of $20 \%$ to $50 \%$ is evidenced, this is due to the high percentage of cement replacements by recycled concrete powder, the available amount of calcium hydroxides $(\mathrm{CH})$ decreases (it is formed during the cement hydration process), the decrease in $\mathrm{CH}$ decreases the possibility of formation of additional hydrated gels in the voids generated during the hydration process of the cement particles, voids that, due to the decrease of the cement particle, are increased, so that the densification of the mixture decreases and with it the resistance to compression. In addition to the aforementioned (Shi, et al., 2012) concludes that the main reason for the decrease in compressive strength in cases of RCP replacement by cement mix aggregates, is due to the fact that curing at high temperature (70-90) ${ }^{\circ} \mathrm{C}$, causes unevenly accelerated cement hydration, and consequently the hydration products were not evenly distributed (most of them accumulated around the unreacted cement particles), resulting in low-density structure formation, which means that the RCP subtracts water from the cement particles and in terms of volume it accelerates the curing process of the mentioned particles, but without time for their adequate homogenization.
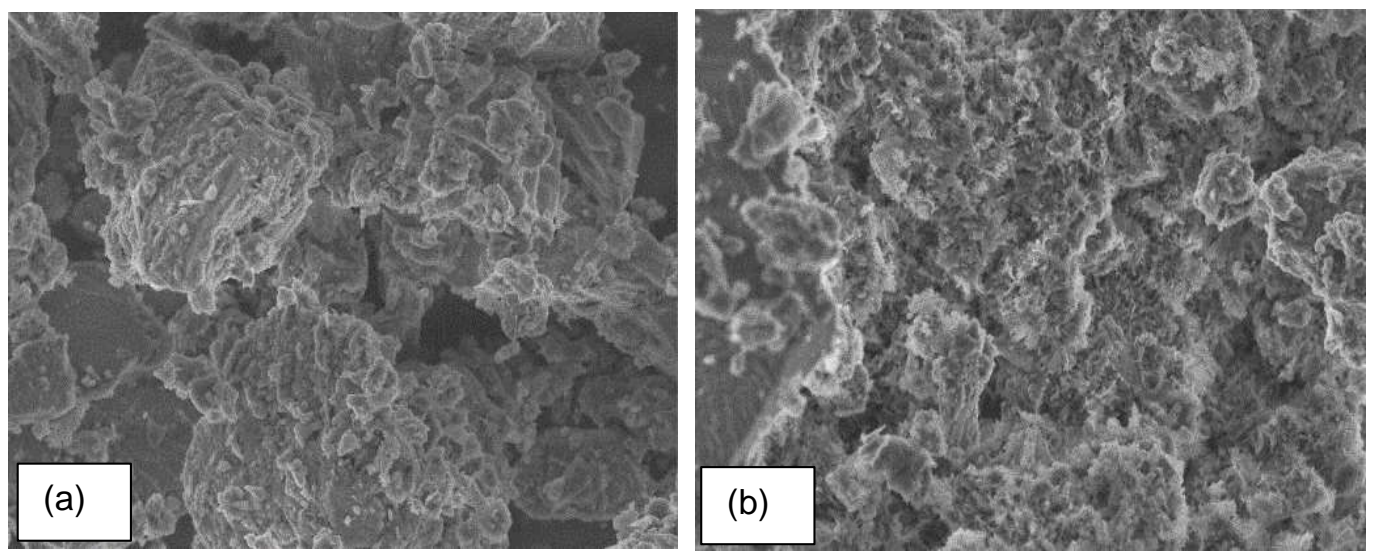

Figure 3. SEM microscopy of mortars obtained. (a) Cement mortar without replacement; (b) Cement mortar and $10 \%$ recycled concrete powder replacement

\section{Conclusions}

From the results obtained, we conclude that the replacement of RCP by PC increased the value of compressive strength, the largest increase being with $10 \%$ replacement, the increase obtained is $17.28 \%$, compared to the initial value of the traditional PC mortar, It is due to the increase in the densification of the mixture, due to the possibility of the formation of extra gels that occupy the empty spaces left during the curing of the traditional PC mortar.

\section{Acknowledgments}

Our special thanks to the Composite Materials Laboratory of the School of Materials Engineering for their support in the development of this research. 


\section{SE \\ Journal of Sciences and \\ Engineering}

Vol. 5, N², 2021

Copyright (c) 2021, CINCADER.

ISSN 2523-9503

DOI: https://doi.org/10.32829/sej.v5i2.149

\section{CINCADER}

Centre of Research and Training for

Regional Development Online at www.journals.cincader.org

\section{References}

Bravo,

N.,

2011.

Concretos

reciclados.

[Online] http://www.concretosreciclados.com.mx/index.php

Cabrera Alvarez, J. L., Urrutia, F., Deborah, L. \& Fernández, A., 1997. Morteros de albañilería con escombros de demolición. Materiales de construcción, 47(246), pp. 43- 48.

Lima Chamber of Commerce, 2019. [Online]. https://www.camaralima.org.pe/wp-content/uploads/2020/09/191014.pdf

Mesgari, Sara \& Akbar Nezhad, Ali \& Xiao, J.Z. 2020. Recycled geopolymer aggregates as coarse aggregates for Portland cement concrete and geopolymer concrete: Effects on mechanical properties. Construction and Building Materials. 236. 117571. Doi: 10.1016/j.conbuildmat.2019.117571.

$\mathrm{Ng}$, Connie \& Alengaram, U. Johnson \& Wong, Leong \& Mo, Kim Hung \& Jumaat, Zamin \& Ramesh, S. 2018. A review on microstructural study and compressive strength of geopolymer mortar, paste and concrete. Construction and Building Materials. 186. 550-576. 10.1016/j.conbuildmat.2018.07.075.

Rakhimova, N. \& Rakhimov, Ravil. 2015. Alkali-activated cements and mortars based on blast furnace slag and red clay brick waste. Materials \& design. 85. 324-332. 10.1016/j.matdes.2015.06.182.

Shi XS, Collins FG, Zhao XL, Wang QY. 2012, Mechanical properties and microstructure analysis of fly ash geopolymeric recycled concrete. J Hazard Mater;237-238:20-9. Doi: 10.1016/j.jhazmat.2012.07.070. 